研

究

\title{
誘導焼結法による炭素鋼の急速焼結技術の開発
}

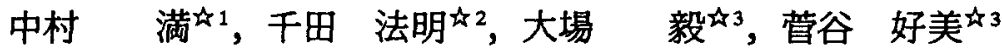 \\ 41岩手大学工学部, 干 020-8551 盛岡市上田 4-3-5. 2 岩手大学大学院, $\overline{0} 020-8551$ 盛岡市上田 4-3-5. \\ 43 日立粉末冶金(侏)，广271-2295 松戸市稔台 520.
}

\section{Development of Rapid Sintering Technique on Carbon Steels by the Induction Heating Method}

\author{
Mitsuru Nakamura ${ }^{\text {th } 1}$, Noriaki Chida ${ }^{\text {th }}$, Takeshi Ohba ${ }^{\text {th } 3}$ and Yoshimi Sugaya 3 \\ ${ }^{1}$ Fac. Eng., Iwate University, 4-3-5 Ueda, Morioka 020-8551. 2Graduate Student, Iwate University, 4-3-5 Ueda, Morioka 020-8551. \\ ${ }^{3}$ Hitachi Powdered Metals Co.,Ltd., 520 Minoridai, Matsudo 271-2295.
}

Received Junuary 11, 1999

\section{SYNOPSIS}

From the purpose of rapid sintering technique within a few minutes, this study was used the green compact of die assembly's lubricant method. Specimen were composited 0.8 mass $\% \mathrm{C}-1.5 \mathrm{mass} \% \mathrm{Cu}$-bal. Fe powders, and used to the high frequency induction heating instrument. By the rapid sintering method, there is very important factor both the removal of adsorbed gas in powder grain surface and accompanied by the diffusion and sintering of each powder. As a result, the isothermal treatment $(1223 \mathrm{~K}-90 \mathrm{~s})$ when the sintering process in this experiment was a key technology treatment. That is to say, this new sintering method obtaind more radial crushing strength values than that of the conventional furnance process. This method was finished to sinter only 3 minutes, and it's condition was maximum heating time-30s, sintering condition $1523 \mathrm{~K}-60$ s and isothermal treatment-90s holding only. KEY WORDS

rapid sintering technique, induction heating method, isothermal treatment, radial crushing strength, release of adsorbed gas

\section{1 緒 言}

近年, 種々の工業分野において製造工程の短縮, 高速化及 び自動化が進められており，省力化と無人化が急速に浸透し てきている。一方，焼結機械部品の製造過程の中では焼結工 程が最も時間と工費を要し，工程の短縮化と高速化は他の分 野のみならず，その前後の工程と比較しても著しく遅れてい る感がある.例えば一般的なメッシュベルト式連続炉では3.5 〜 4.0kWh/kgといわれており,さらに雾囲気制御のための不活 性ガスは $0.5 \sim 1 \mathrm{~m}^{3} / \mathrm{kg}$ と大量に導入されておりこれも経済的 に大きな負担である.

焼結を短時間で行う方法としては，現在通電焼結や放電焼 結(SPS)が一部の焼結しにくい材料に適用 1,2) されているが， これは特殊用途に限られ一般の鉄系や銅系の焼結機械部品へ の応用例はほとんど報告がない。これは，つまりこれらの方 法では現有の生産性と経済性の面で，一般焼結機械部品への 適用は極めて難しいと考えられるためである。

本研究は，きわめて短時間で焼結できる方法として誘導焼 結法を用いた，誘導焼結は鉄系材料では急激な昇温が可能で
あり，省エネルギーの観点からも現状の処理と比較して大幅 に有効であるとされている ${ }^{3 \cdot 5)}$. しかし，誘導加熱で圧粉体を 昇温する場合，溶製材では効率よく加熱され急激に昇温する のに対して，正粉体の場合には，室温から約 1073K 域の昇温 に多くの時間を必要と報告6.わされている.この昇温するまで に要する時間は潜伏期間(Incubation period) ${ }^{7.8)}$ と言われており, 出力, 利用周波数, コイル形状, 压粉体形状及び材料組成な どによっても異なるが，その後の昇温速度と比較すると非常 に長く，全焼結過程を短縮したい誘導焼結法においては大き な問題点となる．またエネルギー効率の面からも，負荷のほ とんどを占める潜代期間を短くすることが重要と考えられた． そこで，本研究では省エネルギー及ひ罧境污染対策の観点 より，急速焼結技術を開発を目的に，昇温速度，粉末粒子表 面の活性化処理, 最高加熱温度及び冷却時間等の種々の因子 について個々に検討を加え，最適かつ最速焼結技術を開発及 び急速焼結のメカニズムの検討を目的で行ったものである.

\section{2 実験方法}


実験に用いた試料の組成は $\mathrm{Fe}+1.5 \mathrm{mass} \% \mathrm{Cu}+0.8 \mathrm{mass} \% \mathrm{C}$ と し,金型潤滑により可能な限りバインダーの量を少なくした. また, 成形密度は $6.8 \mathrm{~g} / \mathrm{cm}^{3}$ と一定とした。試験片形状は外形 $27.03 \mathrm{~mm}$, 内径 $16.03 \mathrm{~mm}$ 及び高さ $10 \mathrm{~mm}$ のリング状の試験片 を成型した.焼結条件としては高周波加熱装置(富士電波工機 製 /THERMECMASTOR Z: PCD制御, PR熱電対対応)を用い, 出力 $15 \mathrm{~kW}$, 周波数 $100 \mathrm{kHz} \pm 10 \%$ で $10^{-4}$ torr 程度の真空中で昇 温速度を 5〜 50K/s, 焼結温度を 1523〜 1623K-60s 保持, 粉末 粒子表面を活性化させる目的で昇温途中に 523K-60s (I.T.1 処 理 : Isothermal Treatment の略)の恒温保持を入れた.これは, 粒子表面の吸着ガスを取るためと脱バインダーが目的7,8)であ る.一方, 1223K (I.T.2 処理)の保持では脱ガス, 黒鉛のマト リックスへの拡散及びオーステナイト化の促進が目的である. これらの条件で 60〜 150 sと保持時間を変化させて実験を行っ た. また, 試料表面をべイナイト化させる目的で冷却時間も 10〜100s と変化させて実験した.

\section{3 実験結果及び考察}

急速加熱で焼結を行う場合, 昇温速度が速いため通常の焼 結温度(約 $1400 \mathrm{~K}$ )では反応が十分進まず焼結が不完全だと考 えられる.そこで本実験では初めに, 最高加熱温度の影響を 検討した. Fig.1 は衝撃試験片 (JIS Z2442)を用いて昇温速度を $5 \mathrm{~K} / \mathrm{s}$ 一定とし, 焼結温度を 1523,1573 及び $1623 \mathrm{~K}$ とした時の 外表面(Edge)と中心部(Center)のミクロ組織を示す. 1623Kで は Centerに直線状のセメンタイトが見られる.この異常なセ メンタイトの析出により, 試料は溶融してしまった.一方,

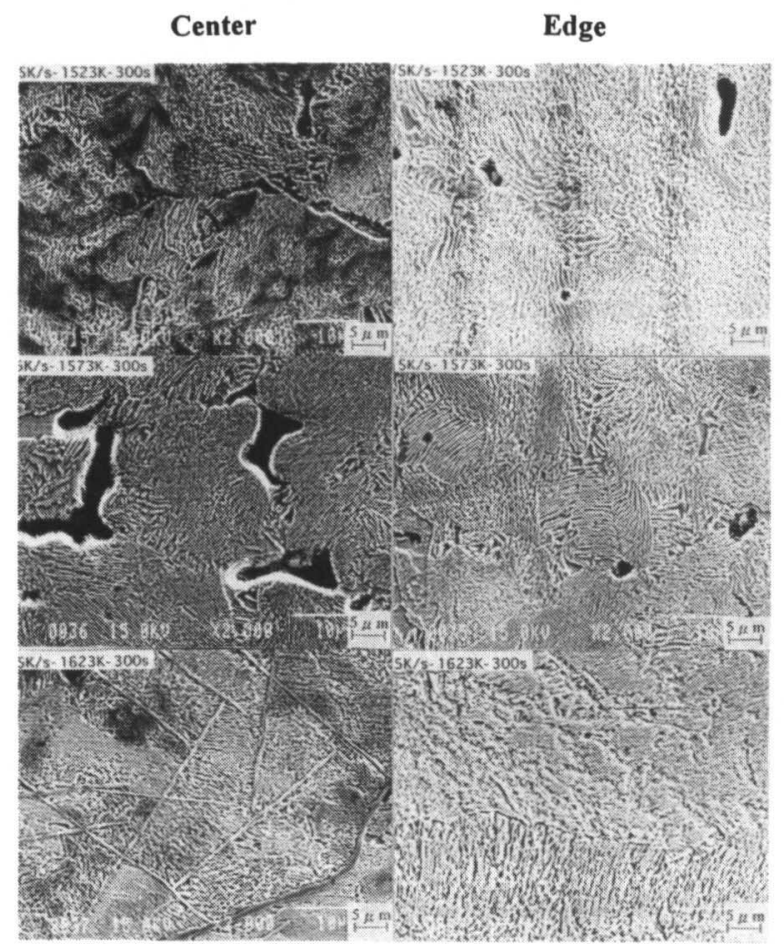

Fig.1 SEM photographs of 3 types sintering temperature condition both center and edge parts. (heating rate $5 \mathrm{~K} / \mathrm{s}$ const.)
1523 及び1573Kの試料はほぼオールパーライトになっている が, $1573 \mathrm{~K}$ の試料は試料表面が変形した。この結果，本実験 では焼結温度は最も低い $1523 \mathrm{~K}$ 一定とした．また，ミクロ組 織の比較では誘導加熱による表皮効果の影響で Center では Edgeに比べ気孔が比較的多かった.

次に焼結過程での固溶及び析出反応を調ぺるため, DTAに よる測定を行った. DTAの条件は, $\mathrm{Ar}$ 雾囲気中で昇温速度が

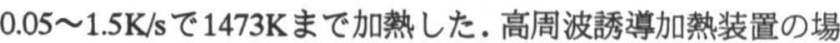
合, 昇温速度は数十倍程度になるが, DTA装置の限界が $100 \mathrm{~K} /$ minのため, この昇温速度で粉末粒子の基礎物性挙動の把握 を行った. Fig.2 は DTAの測定結果を示す.上のグラフの $1360 \mathrm{~K}$ 付近は銅 $(\mathrm{Cu})$ の溶融反応を示しており, 中央のグラフ の $1190 \mathrm{~K}$ 付近は $\alpha$ から $\gamma$ の変態, 一方, 下のグラフの $1050 \mathrm{~K}$ 付近は黒鉛のマトリックスへの拡散と吸着ガスの放出の反応 が主として表れていると思われる.これらグラフは昇温速度 が速くなるにつれて各反応温度が高くなる傾向を示した。こ の実験結果から各反応を確かめるために各温度での組織変化 を検討した。

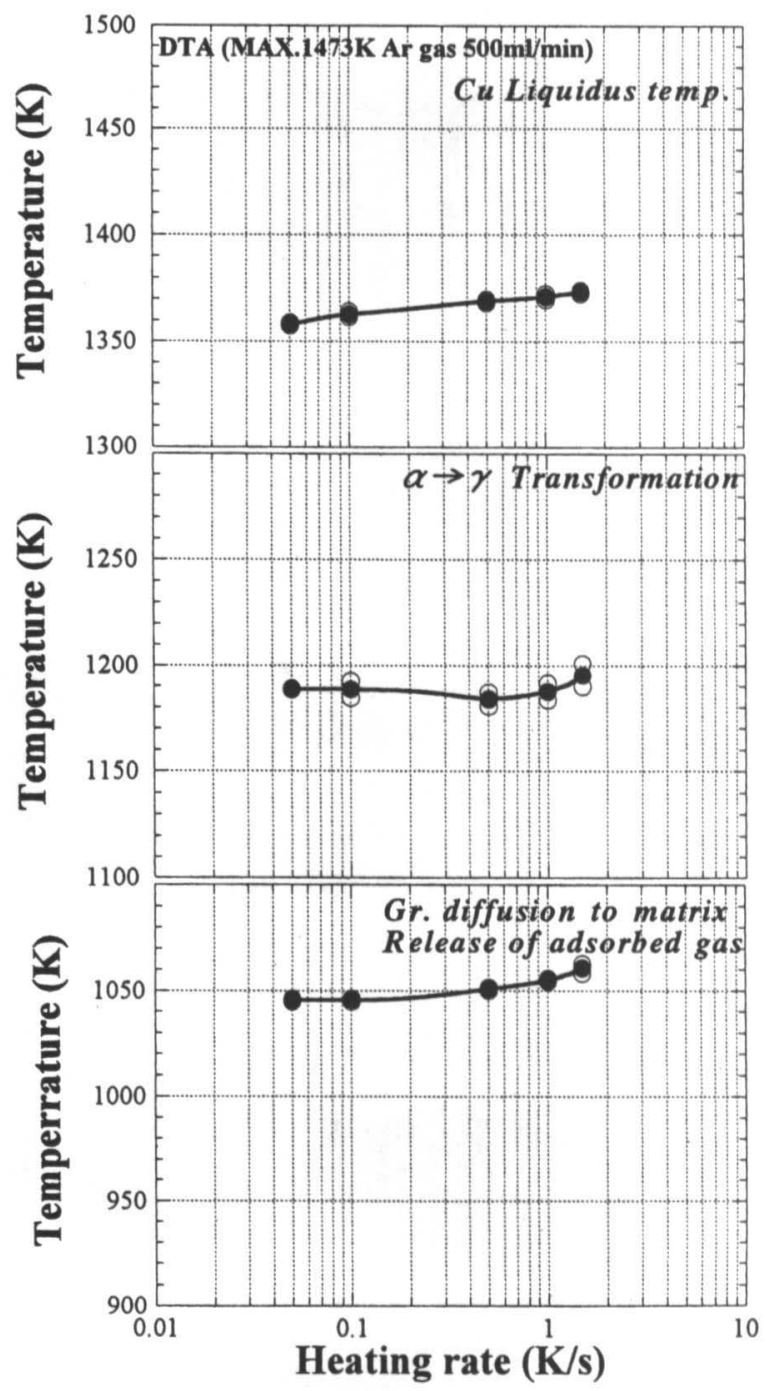

Fig.2 DTA results between heating rate and heating temperature. 


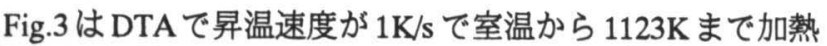
した後，急冷したミクロ組織を示す．この処理で，C分析を 見ると黒鉛はほとんど拡散していないことがわかった.また $\mathrm{O}_{2}$ 分析でも吸着ガスもほとんど放出していないことが判明し た. すなわち, DTAの結果とは反応温度が多少異なる傾向が 認められた.

Fig.4 は DTA で同様に Fig.3の試料よりさらに 100K 上げて $1223 \mathrm{~K}$ まで加熱した後, 急冷したミクロ組織を示す. $\mathrm{O}_{2}$ 分析 を見るとガスはほぼ放出していることがわかる．黒鉛は短時 間処理のためあまり拡散していないが, 水冷したために組織 はマルテンサイト組織になっていた.

一方, Fig.5 は DTA で同様に $1223 \mathrm{~K}$ まで加熱し，今度はそ の温度で $300 \mathrm{~s}$ 保持した後, 急冷したミクロ組織を示す. 吸着

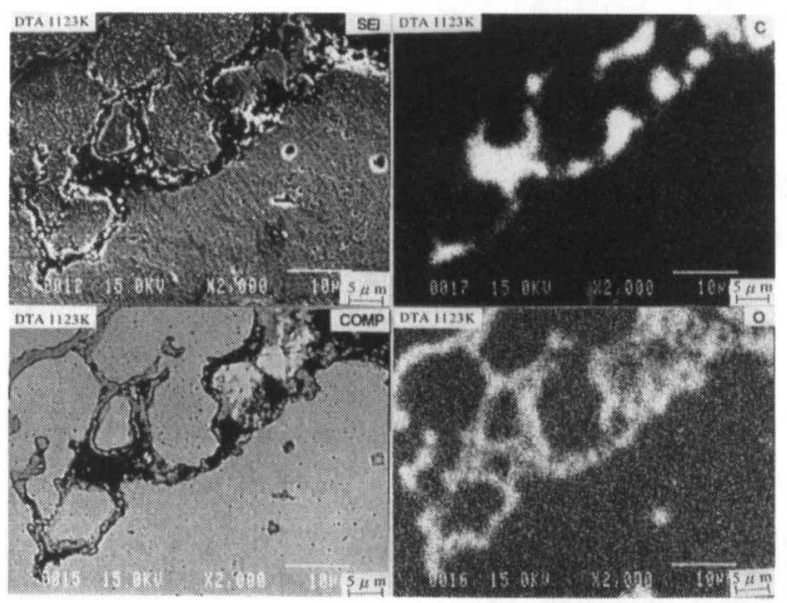

\section{R.T. $\rightarrow 1123 \mathrm{~K} \rightarrow$ W.Q. (heating rate:1K/s)}

Fig.3 EPMA analysis of $\mathrm{C}$ and $\mathrm{O}_{2}$ elements obtained by DTA results.

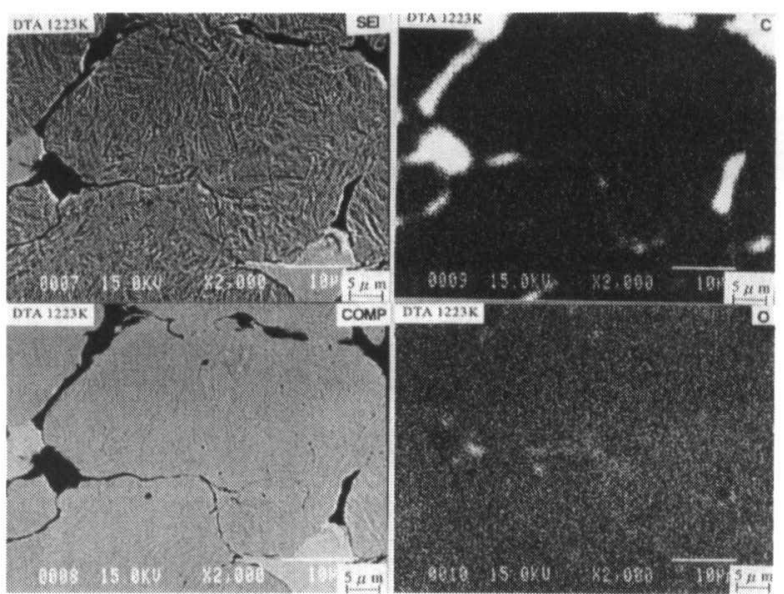

R.T. $\rightarrow 1223 \mathrm{~K} \rightarrow$ W.Q. (heating rate: $1 \mathrm{~K} / \mathrm{s}$ )

Fig.4 EPMA analysis of $\mathrm{C}$ and $\mathrm{O}_{2}$ elements obtained by DTA results.
ガスはほぼ放出しており，黒鉛もかなり拡散していることが わかる. また, 結晶粒が再結晶しており, 焼結がかなり進ん でいることが判明した.このDTAの結果から, 本実験の目的 である急速加熱中，1223K で恒温保持することは急速焼結で は重要な因子と考えられた。

これらの結果より, リング状試験片での焼結条件は以下の ようにした. すなわち昇温速度 5〜50K, 焼結温度 $1523 \mathrm{~K}-60 \mathrm{~s}$ 一定, 1073〜673Kまでの冷却時間10１00s, さらに I.T.1,I.T.2 処理をそれぞれ 60s 行う場合と, 行わないすなわち通常焼結 に分けてそれぞれ検討した。

Fig.6は昇温途中に I.T. 処理をしていない Normal Sintering (通常焼結)での圧環強さと冷却時間及び圧環強さと昇温速度 の関係を示している. 昇温速度が 5,10 及び $20 \mathrm{~K} / \mathrm{s}$ では冷却時 間が 10,20 と速い時は約 $950 \mathrm{~N} / \mathrm{mm}^{2}$ と連続炉で焼結した時の 圧環強さ (約 $833 \mathrm{~N} / \mathrm{mm}^{2}$ ) を越えている.これは冷却時間が速 いため試料表面のミクロ組織がベイナイト化したためであっ た.一方, $50 \mathrm{~K} / \mathrm{s}$ の試料は冷却時間を変えても通常の連続炉の 圧環強さをかなり下回った. また,この通常焼結では昇温速 度の限界は $30 \mathrm{~K} / \mathrm{s}$ 程度であった.

Fig.7は Normal Sintering でのミクロ組織を示す. 昇温速度か $20 \mathrm{~K} / \mathrm{s}$, 冷却時間が 10 及び $50 \mathrm{~s}$ でのミクロ組織を示す. 試料表 面付近の組織を見ると, $50 \mathrm{~s}$ に比べ $10 \mathrm{~s}$ の試料が一部べイナイ 卜化していることがわかる. また, 黒鉛も存在しているが, マ トリックスが強化されたために比較的低速の昇温速度では強 度が出ていた。

Fig.8 は Fig.2 の結果から脱ガスと黒鉛の拡散が主目的の I.T.2処理をした試料の圧環強さと冷却時間及び圧環強さと昇 温速度の関係を示す. 昇温速度が 5,10 及び $20 \mathrm{~K} / \mathrm{s}$ の試料は, ど の冷却時間でも連続炉での圧環強さを越えている.これはI.T. 処理をすることにより, 試料内部まで十分焼結が進んだため と考えられた。一方, 昇温速度の限界は Fig.6 と同様に $30 \mathrm{~K} / \mathrm{s}$

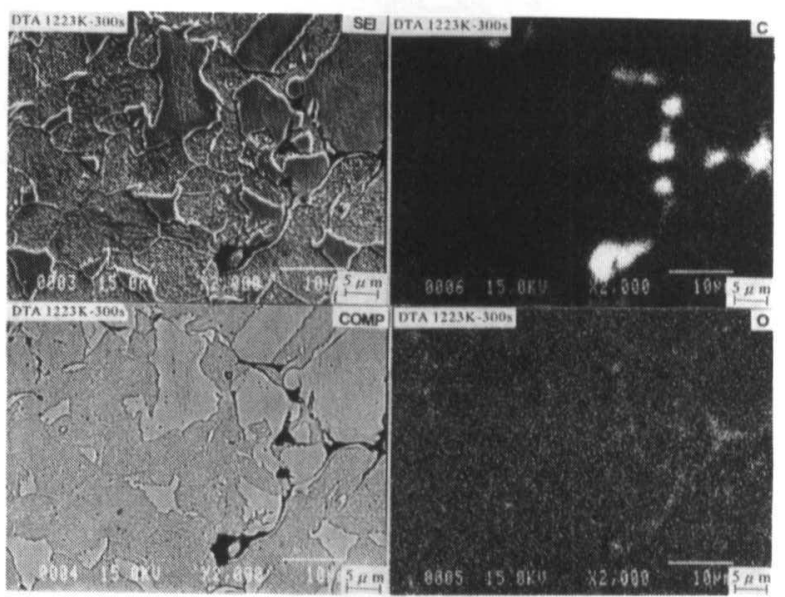

R.T. $\rightarrow 1223 \mathrm{~K}-300 \mathrm{~s} \rightarrow$ W.Q. (heating rate: $1 \mathrm{~K} / \mathrm{s}$ )

Fig.5 EPMA analysis of $\mathrm{C}$ and $\mathrm{O}_{2}$ elements obtained by DTA results. 

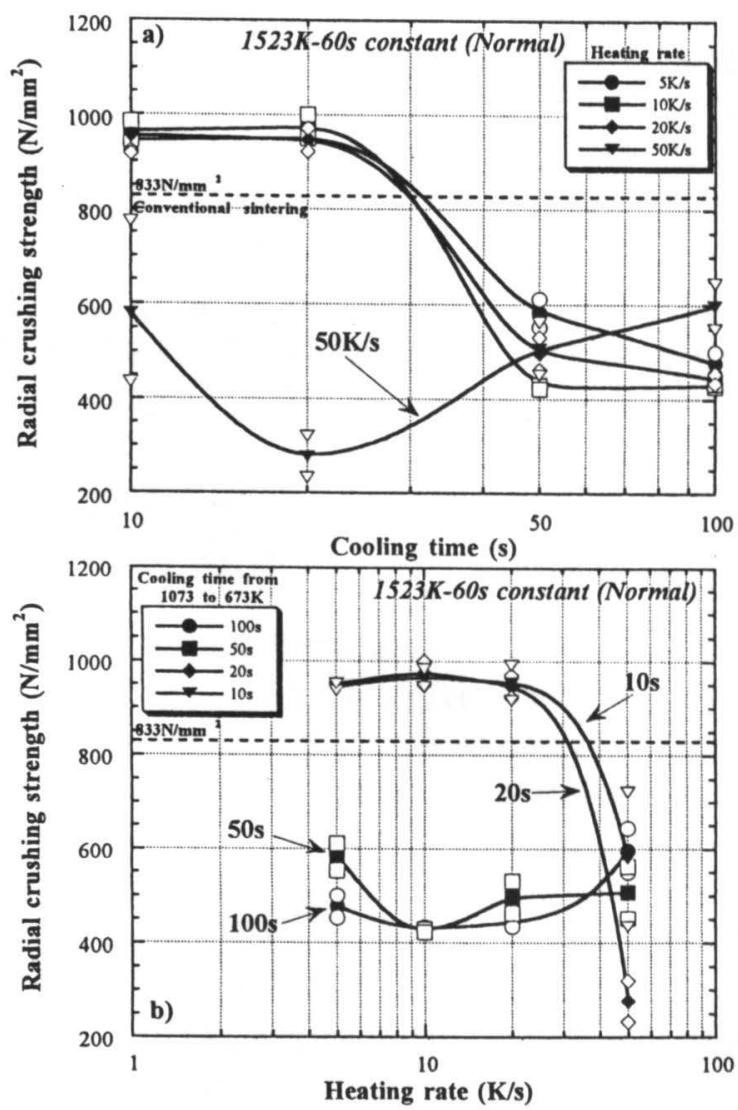

Fig.6 Relation between the radial crushing strength, cooling time and heating rate. (Normal sintering condition)

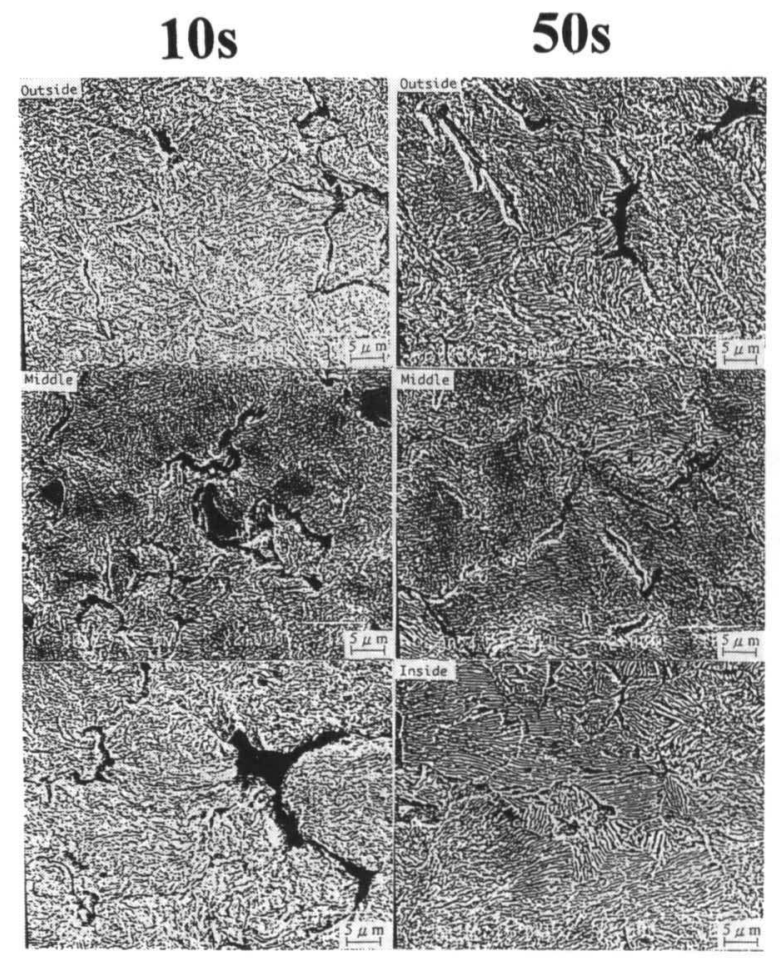

Fig.7 SEM photographs of 2 types cooling time specimens on normal sintering condition.
程度だと思われる．しかし，かなりの高範囲での冷却速度で 十分圧環強さが得られたのは, このI.T.2処理の有効性を示し ている.

Fig.9は比較のためI.T.1+I.T.2処理をした試料の同様の関係 を示している.この試料も Fig. 8 と同様に, 昇温速度か 5,10 及 び 20K/s の試料はどの冷却時間でも通常の圧環強さを大幅に 越えており, Fig.8より約 $50 \mathrm{~N} / \mathrm{mm}^{2}$ 高い值を示していた.一方， 昇温速度の限界は同様に $30 \mathrm{~K} / \mathrm{s}$ 程度であった。

Fig.10は Fig.8及び Fig.9 の昇温速度 20K/s で冷却時間 $50 \mathrm{~s}$ の ミクロ組織を示す. 外表面に未反応の黒鉛が若干残るが, Fig.6と比べると内側はほぼ全面がパーライトになっている. このように, 誘導焼結では I.T. 処理は非常に有効であると考 えられる.しかし, I.T.2のみとI.T.1+I.T.2 処理の相違はミク 口組織上, 明瞭な差は認められなかった.

Fig.11 は本実験の目的である数分以内で焼結を終わらさせ るために昇温速度の限界を調べた. 四に示すようにI.T.2処理 をしたものは約30〜35K/sに限界があり, I.T.1+I.T.2処理した 試料は約 35 40K/sに限界があった.この結果, 最速では, 冷 却過程を考虑に入れないと $2.5 \sim 3.5$ 分以内で焼結が完了する ことが判明した。

一方, I.T.2 処理を $60 \sim 150$ s まで変化させ, 各種試験した結 果, $1223 \mathrm{~K} て ゙ 90 \mathrm{~s}$ 以上保持すると $40 \mathrm{~K} / \mathrm{s}$ の昇温速度でも十分通 常連続炉での強度レベルを越える試料が得られた。
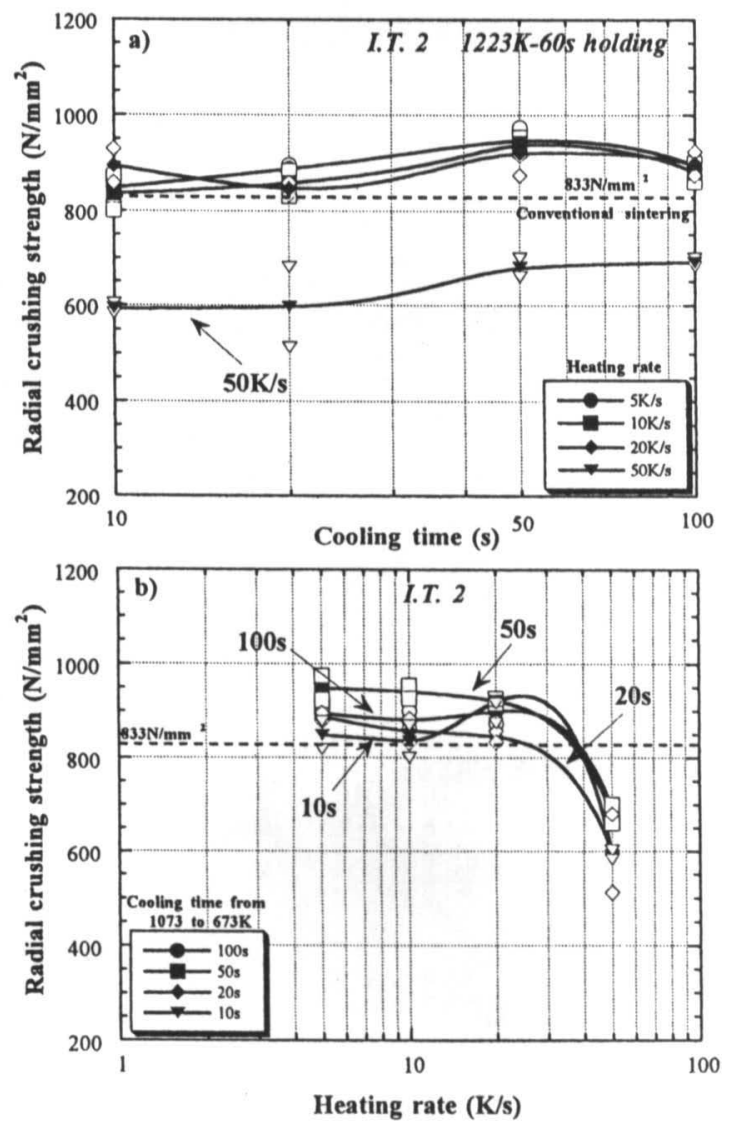

Fig.8 Relation between the R.C.S., cooling time and heating rate. (I.T.2 condition) 

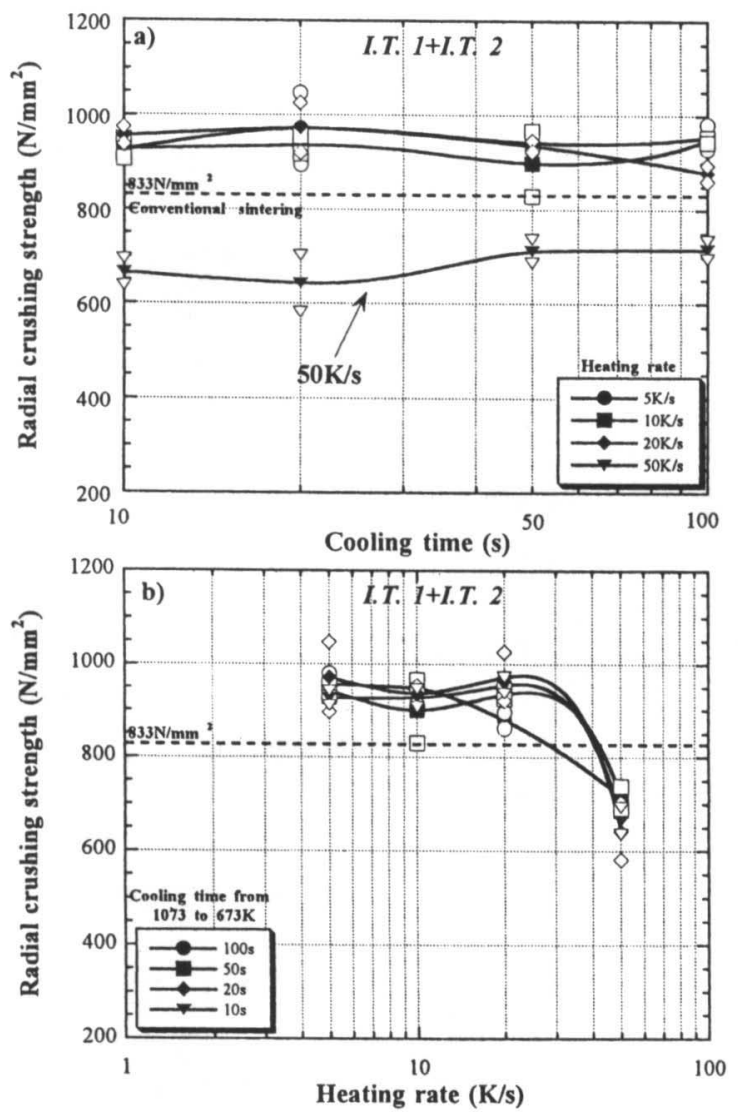

Fig.9 Relation between the R.C.S., cooling time and heating rate. (I.T. 1+I.T. 2 conditions)

\section{I.T. 2}

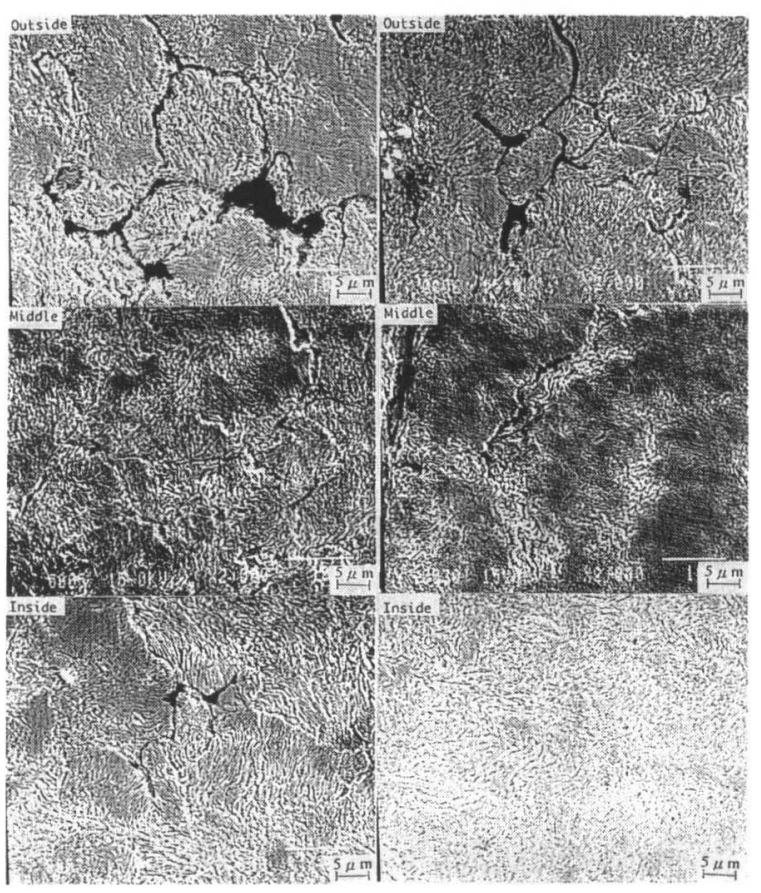

Fig.10 SEM photographs of 2 types isothermal treatment specimen.
さらに，製品に重要な寸法変化率について検討した結果, この誘導加熱法では全て膨張方向に変化が見られ最大 $0.25 \%$ 程度の膨張が認められた.この寸法変化率は今後さらに小さ くすべく詳細に検討する予定である.

\section{4 結 論}

型潤滑によるバインダーレス炭素鋼 (0.8mass\%C-1.5mass\% $\mathrm{Cu}-\mathrm{Bal} . \mathrm{Fe})$ 圧粉体を用い, 高周波誘導加熱法による数分以内の 急速加熱焼結技術の開発を目的に実験を行った結果, 以下の 結論を得た。

(1) 焼結過程で恒温保持処理(Isothermal Treatment)を行わない 通常焼結法では, 粉末粒子表面の脱ガス, マトリックスへ の黒鉛の拡散が不十分なため昇温速度か $30 \mathrm{~K} / \mathrm{s}$ 以内かつ泠 却時間 $10 s$ 及び $20 s$ の速い条件でのみしか, 通常の連続炉 で焼結した圧環強さ以上は得られなかった.

(2) I.T.2 処理 $(1223 \mathrm{~K}-60 \mathrm{~s})$ を行った急速焼結法では脱ガス, 黒 鉛の拡散がかなり進み昇温速度30 35K/s以内でかつ全て の泠却時間で通常の圧環強さを越えた.

(3) I.T.1処理 $(523 \mathrm{~K}-60 \mathrm{~s})+\mathrm{I}$.T.2処理を行った急速加熱法は, (2) よりさらに焼結反応が進むために昇温速度 $35 \sim 40 \mathrm{~K} / \mathrm{s}$ 以内 の条件で,さらに圧環強さが上昇した. 但し, I.T.1処理の 効果はほとんど無く, 本実験ではむしろI.T.2処理を60s か ら 90sに長くした方が, 良好な結果が得られた.
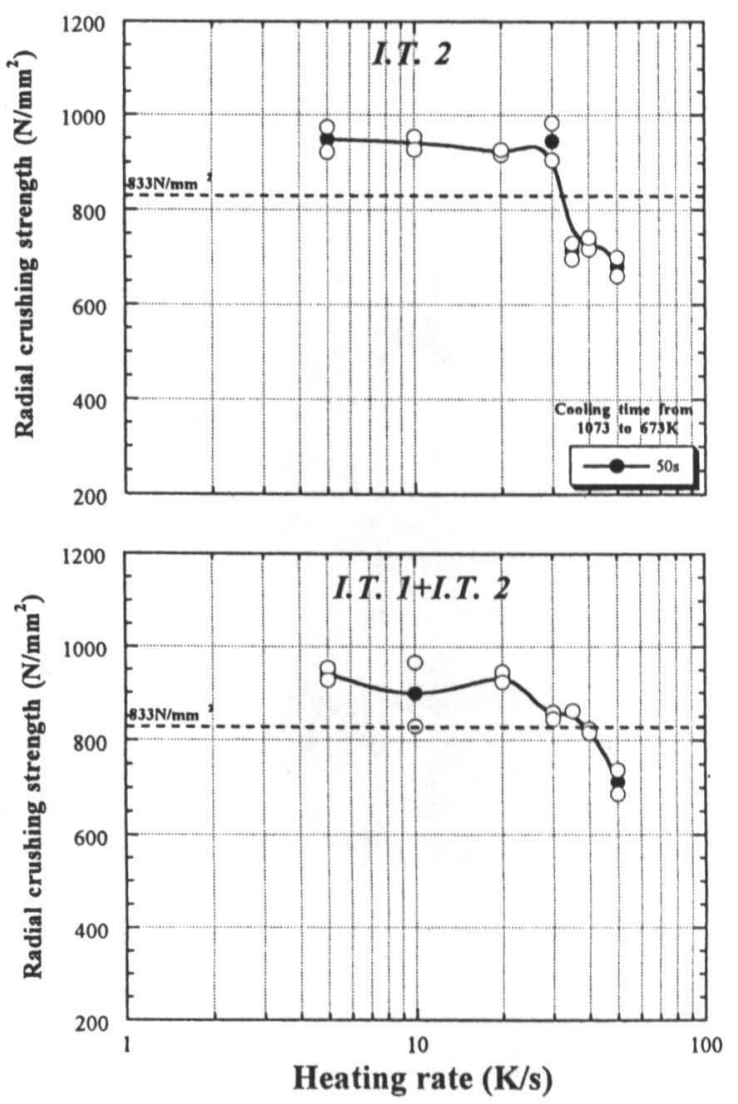

Fig.11 Relation between the R.C.S. and heating rate on difference of 2 types isothermal treatment. 
(4)この結果, 冷却過程を考虑しないと最速昇温時間 $30 s$, I.T.2 処理 90s，焼結温度 $1523 \mathrm{~K}-60 \mathrm{~s}$ ，すなわち $180 \mathrm{~s}$ (3 分) で焼結の全工程が終了することが判明した。

(5) 寸法変化率は現在まで外径,内径ともいずれも膨張傾向で 最大 $0.25 \%$ が得られた.これは誘導加熱による表皮効果 (Skin effect)で試料内外で温度差が 40K 表れるためであっ た. 今後,さらに変化率を小さくすべく検討中である.

\section{文献}

1）望月，三上,小川他："通電粉末圧延技術の開発",まてり あ, 37(1998)280-282.

2) 大森, 平井: "放電ブラズマシステム(SPS)", まてりあ, 37 (1998) 295.

3) R.Krumphold, W.Hernel and G.Leitner: "Short-Time Induction
Sintering of Fe-Based Materials and Hardmetals", Elsevier Science, (1984)127-138.

4) G.D.Pfaffman and W.E.Templeton: "Induction Heating Temp. Sintering Process and Equipment", Advancesin Powder Metallurgy, 1(1990)399-408.

5) W.Hermel, G.leitner and R.Krumphold: "Review of Induction Sintering: Fundamentals and Applications", Powder Metallurgy, 3(1980)130-135.

6)宮野,井上,柴田: "鉄一黒鉛圧粉体の誘導焼結",粉体およ び粉末治金, 27(1980)11-15.

7）宮野,井上,柴田: "鉄一黒鉛圧粉体の誘導加熱における潜 伏期間について", 粉体および粉末治金, 27(1980)197-200.

8) 遠藤, 久保,森岡,伊藤："鉄粉圧粉体の焼結過程における 電気抵抗変化 ", 粉体および粉末治金, 26(1979)195-200. 